\title{
Immunohistochemical analysis of 2,3,7,8-tetrachlorodibenzo-p-dioxin (TCDD) toxicity on the developmental dentate gyrus and hippocampal fimbria in fetal mice
}

\author{
Yoshihiro KOBAYASHI ${ }^{1)}$, Tetsushi HIRANO ${ }^{1)}$, Takuya OMOTEHARA ${ }^{1)}$, Rie HASHIMOTO ${ }^{1)}$, Yuria UMEMURA ${ }^{1)}$, \\ Hideto YUASA ${ }^{2}$, Natsumi MASUDA ${ }^{2)}$, Naoto KUBOTA ${ }^{1)}$, Kiichi MINAMI ${ }^{1)}$, Shogo YANAI ${ }^{1)}$, \\ Mitsuko ISHIHARA-SUGANO ${ }^{3)}$, Youhei MANTANI ${ }^{2)}$, Toshifumi YOKOYAMA ${ }^{1)}$, Hiroshi KITAGAWA ${ }^{2)}$ \\ and Nobuhiko HOSHI ${ }^{1) *}$ \\ 1) Laboratory of Molecular Morphology, Department of Animal Science, Graduate School of Agricultural Science, Kobe University, Kobe, \\ Hyogo 657-8501, Japan \\ ${ }^{2)}$ Laboratory of Histophysiology, Department of Animal Science, Graduate School of Agricultural Science, Kobe University, Kobe, Hyogo \\ 657-8501, Japan \\ 3) Frontier Research Laboratory, Corporate Research and Development Center, Toshiba Corporation, Saiwai, Kawasaki, Kanagawa \\ 212-8582, Japan
}

(Received 20 April 2015/Accepted 20 May 2015/Published online in J-STAGE 21 June 2015)

ABSTRACT. Dioxins are widespread persistent environmental contaminants with adverse impacts on humans and experimental animals. Behavioral and cognitive functions are impaired by 2,3,7,8-tetrachlorodibenzo- $p$-dioxin (TCDD) exposure. TCDD exerts its toxicity via the aryl hydrocarbon receptor (AhR), a ligand-activated transcription factor. The hippocampus, which plays important roles in episodic memory and spatial function, is considered vulnerable to TCDD-induced neurotoxicity, because it contains the AhR. We herein investigated the effects of TCDD toxicity on hippocampal development in embryonic mice. TCDD was administered to dams at 8.5 days postcoitum with a single dose of 20, 200, 2,000 and 5,000 $\mathrm{ng} / \mathrm{kg}$ body weight (groups T20, T200, T2000 and T5000, respectively), and the brains were dissected from their pups at embryonic day 18.5. Immunohistochemical analysis demonstrated that the Glial Fibrillary Acidic Protein (GFAP) immunoreactivities in the dentate gyrus (DG) were reduced in the T5000 group. Granular GFAP immunoreactivity was observed in the hippocampal fimbria, and the number of immunoreactive fimbria was significantly decreased in the T5000 group. The number of Proliferating Cell Nuclear Antigen (PCNA)-positive cells was decreased in all TCDD-exposed groups and significantly reduced in the T20, T200 and T5000 groups. Together, these results demonstrate that maternal TCDD exposure has adverse impacts on neural stem cells (NSCs), neural precursor cells (NPCs) and granular cells in the DG and disrupts the NSC maintenance and timing of differentiation in the hippocampal fimbria, which in turn interrupt neuronal development in future generations of mice.

KEY WORDS: aryl hydrocarbon receptor (AhR), dentate gyrus, Glial Fibrillary Acidic Protein (GFAP), hippocampus, 2,3,7,8-tetrachlorodibenzo- $p$-dioxin (TCDD)

doi: 10.1292/jvms.15-0238; J. Vet. Med. Sci. 77(11): 1355-1361, 2015

Endocrine-disrupting chemicals (EDCs) are exogenous chemicals that have various adverse effects on the endocrine system by interfering with the hormonal signaling. Dioxins, one of the EDCs, are widespread persistent environmental contaminants and are produced by burning waste materials containing chlorine, such as plastics [50]. Polychlorinated dibenzo- $p$-dioxin (PCDD), polychlorinated dibenzofuran (PCDF) and dioxin-like polychlorinated biphenyl (DL-PCB) are called dioxins. 2,3,7,8-tetrachlorodibenzo- $p$-dioxin (TCDD) is a kind of PCDD and is the most toxic chemical among dioxins [46]. TCDD has various adverse impacts on the body weight, sex ratio, reproductive systems and immune systems in humans and experimental animals [16, 19, 20,

*Correspondence to: Hoshi, N., Laboratory of Molecular Morphology, Department of Animal Science, Graduate School of Agricultural Science, Kobe University, 1-1 Rokkodai, Nada-ku, Kobe 657-8501, Japan. e-mail: nobhoshi@kobe-u.ac.jp

C2015 The Japanese Society of Veterinary Science

This is an open-access article distributed under the terms of the Creative Commons Attribution Non-Commercial No Derivatives (by-nc-nd) License $<$ http://creativecommons.org/licenses/by-nc-nd/3.0/>.
$39,40]$. In the central nervous system, it is reported that TCDD exposure induces an aberrational increase of neurons containing tyrosine hydroxylase and cognitive deficits in rhesus monkeys [35] and mice [39].

Dioxins accumulate in maternal adipose tissue and affect not only a dam itself but also its pups [37]. Dioxins contained in maternal blood and breast milk are transferred to the fetal and neonatal circulation via the placenta and lactation $[14,45]$. Moreover, it is suspected that the developing fetus and neonates are vulnerable to dioxins due to the immaturity of the blood-brain barrier. A low dose of TCDD at embryonic day (E) 12.5 actually impairs the executive functions and social behaviors in C57BL/6 mice [10]. Therefore, TCDD can affect development of the brain.

Dioxins exert their toxicity via the aryl hydrocarbon receptor (AhR), a ligand-activated transcription factor belonging to a basic helix-loop-helix/Per-ARNT-Sim (bHLH-PAS) transcription factor superfamily [5]. Upon binding to a ligand, the AhR is translocated into the nucleus and forms a heterodimer with the AhR nuclear translocator (ARNT) [28]. The AhR/ARNT heterodimer recognizes a xenobiotic responsive element (XRE) in the enhancer of 
its target genes and regulates its expression; the XRE is associated with xenobiotic metabolism, cell proliferation, differentiation or apoptosis $[9,26,27]$. AhR mRNA in adult male rats is expressed by the dentate gyrus (DG) in the hippocampus [32], and AhR and ARNT mRNA in the mouse embryo are also present in the neuroepithelium $[1,2]$, suggesting that the hippocampus is vulnerable to TCDDinduced neurotoxicity.

The hippocampus is implicated in the episodic memory and spatial function [34]. It has been reported that the activation of the AhR by TCDD exposure decreases adult hippocampal neurogenesis and impairs contextual fear memory [24]. Furthermore, it was suggested that exposure to EDC (bisphenol A) causes fluctuations in hippocampal neurogenesis in young adult mice that result in spatial learning and memory impairment via a brain-derived neurotrophic factor-independent pathway [21]. However, the effects of TCDD exposure on the hippocampus of future generations of mice remain unclear. In this study, therefore, we investigated the effects of TCDD toxicity on the hippocampal development in embryonic mice.

\section{MATERIALS AND METHODS}

Animals: Female and male C57BL/6N mice were purchased from Japan SLC, Inc. (Hamamatsu, Japan) for breeding stock. The animals used for the experiments were bred in a laboratory at the Department of Animal Science at Kobe University, under a 12 -hr light/dark cycle at $21-24^{\circ} \mathrm{C}$ and 40-60\% humidity. A laboratory diet (Lab MR Stock; Nihon Nosan Co., Yokohama, Japan) and filtered water were available ad libitum. This experiment was approved by the Institutional Animal Care and Used Committee (Permission number: 24-10-03) and carried out according to the Kobe University Animal Experimentation Regulation.

TCDD exposure: The applied dose of TCDD (Wako Pure Chemical Ind., Ltd., Osaka, Japan) was based on the dose associated with the lowest observed adverse effect level (LOAEL) [200 $\mathrm{ng} / \mathrm{kg}$ body weight (BW)] [11, 12]. Laboratory-grade sesame oil was the vehicle for the dosing solutions. The volumes for oral administration were adjusted to $25 \mu l / 30 \mathrm{~g} \mathrm{BW}$ of sesame oil. Female mice in proestrus were mated 1:1 with males overnight, and females that had a vaginal plug on the following morning were designated as being at E0.5. Vehicle or TCDD $(20,200,2,000$ or 5,000 $\mathrm{ng} /$ $\mathrm{kg} \mathrm{BW}$ ) was orally administered on E8.5. These groups were defined as the control, T20, T200, T2000 and T5000 groups, respectively.

Tissue preparation: At the time of necropsy, all dams were deeply anesthetized with diethyl ether. Fetuses were excised at E18.5 from the dam uteri and were weighed. The brains were dissected from the skulls and weighed. They were then fixed in $4 \%$ paraformaldehyde in $0.1 \mathrm{M}$ phosphate buffer overnight at $4^{\circ} \mathrm{C}$, dehydrated through a graded series of ethanol followed by xylene and embedded in paraffin. Coronal serial sections of $10 \mu \mathrm{m}$ thickness were then cut and mounted on a glass slide (Platinum Pro; Matsunami Glass Ind., Ltd., Kishiwada, Japan), and a series of semi-serial sections was made by collection at $100-\mu \mathrm{m}$ intervals (one of every 10 tissue sections).

Cresyl fast violet staining: After deparaffinization and rehydration, the sections were stained with $0.1 \%$ cresyl fast violet solution for $5 \mathrm{~min}$. They were then placed in distilled water and a graded series of ethanol for appropriate bleaching of dye, dehydrated with ethanol and coverslipped with Eukitt (O. Kindler, GmbH, Freiburg, Germany).

Immunohistochemistry and immunohistoplanimetry: The combination of blocking agents and antibodies used for the detection of each protein by immunohistochemistry is listed in Table 1. The sections were deparaffinized and rehydrated and were heated at $121^{\circ} \mathrm{C}$ for $20 \mathrm{~min}$ in $10 \mathrm{mM}$ sodium citrate buffer ( $\mathrm{pH}$ 6.0) for antigen retrieval. After cooling, they were immersed in absolute methanol and $0.5 \% \mathrm{H}_{2} \mathrm{O}_{2}$ for $30 \mathrm{~min}$ each at room temperature (RT) to quench the endogenous peroxidase activity. The specimens were incubated with each blocking agent for $1 \mathrm{hr}$ at $\mathrm{RT}$ and then with each primary antibody for $18 \mathrm{hr}$ at $4^{\circ} \mathrm{C}$ (Table 1). After washing with phosphate buffered saline (PBS), each secondary antibody was reacted for $1 \mathrm{hr}$ at RT (Table 1). The excess antibodies were rinsed in PBS, and the immunoreactivities were detected by incubation with 3,3'-diaminobenzidine solution (EnVision+ kit/HRP [DAB]; Dako, Glostrup, Denmark). The sections were counterstained lightly with hematoxylin. Finally, they were dehydrated and cleared through an ethanol-xylene series and coverslipped with Eukitt (O. Kindler, GmbH).

Table 1. The combination of blocking agents and antibodies used for immunohistochemistry

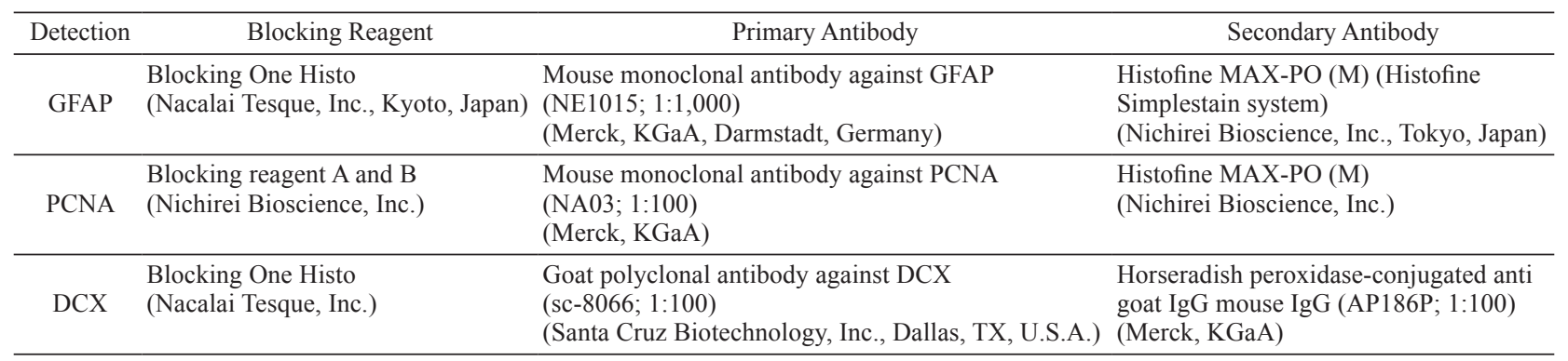

GFAP: Glial fibrillary acidic protein, PCNA: Proliferating cell nuclear antigen, DCX: Doublecortin. 


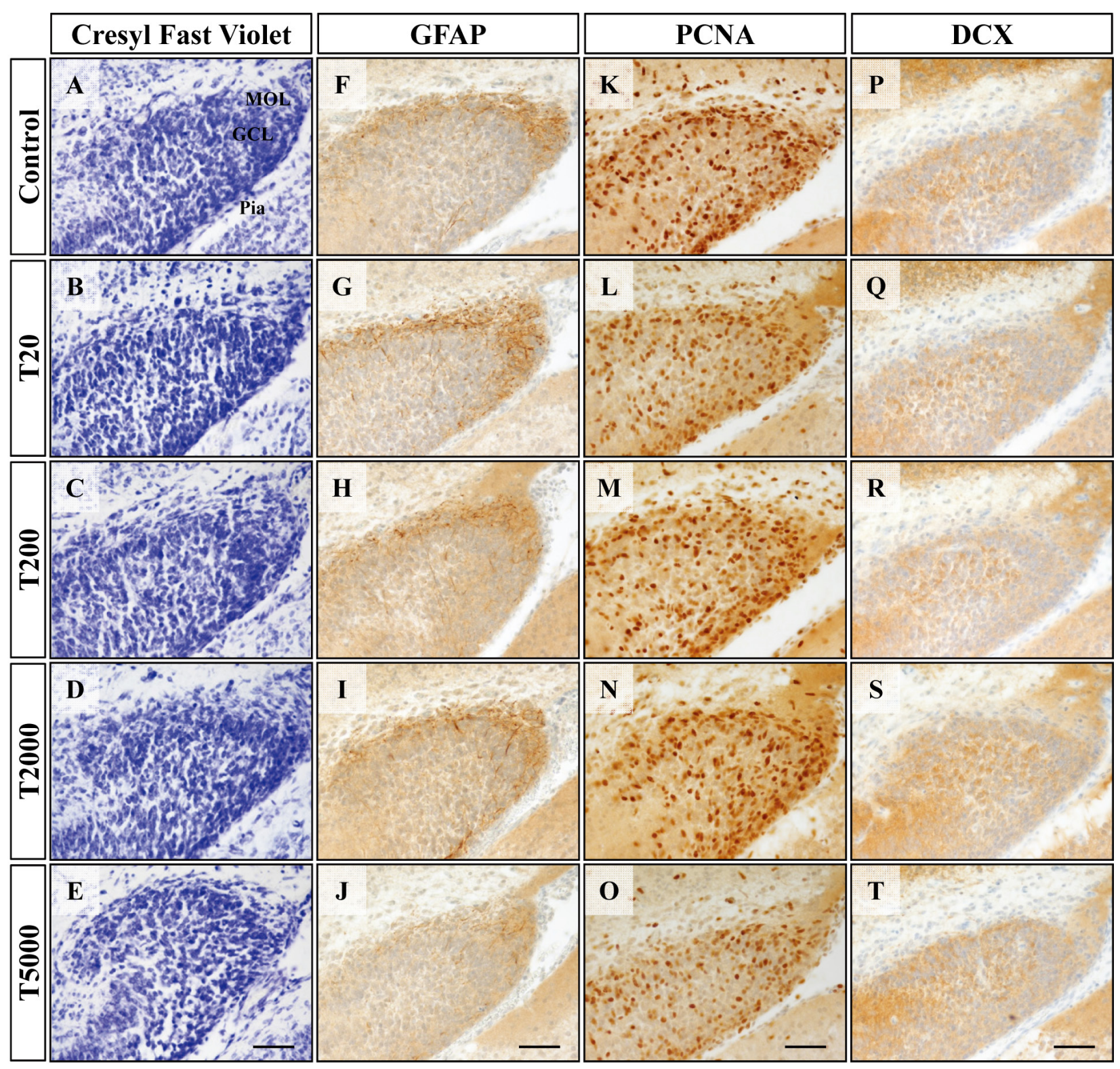

Fig. 1. Representative histology and immunohistochemistry in the DG in the hippocampus at E18.5. (A-E) The cell density in the DG was decreased in the T5000 compared with the control group, whereas no obvious changes were observed in the shape or somatic size of cells (E). (F-J) The fibrous immunoreactivities of GFAP were detected, but were decreased in the T5000 group (J). (K-O) The numbers of PCNApositive cells were smaller in the T5000 $(\mathrm{O})$ than the other groups $(\mathrm{K}-\mathrm{N})$. $(\mathrm{P}-\mathrm{T})$ The intensity of DCX staining did not differ between the control and TCDD-exposed groups. MOL: molecular layer; GCL: granule cell layer; Pia: pia mater; Bar $=50 \mu \mathrm{m}$.

Immunohistoplanimetry: Coronal sections containing the hippocampus stained immunohistochemically were observed under a light microscope (Nikon, Corp., Tokyo, Japan). The granular immunoreactivities of Glial Fibrillary Acidic Protein (GFAP) and Proliferating Cell Nuclear Antigen (PCNA)-positive cells were counted in 3 sections per $100 \mu \mathrm{m}$.

Statistical analysis: Statistical analysis was performed with Excel Statistics 2012 for Windows (SSRI, Co., Ltd., Tokyo, Japan). Results are presented as the mean \pm S.D.
Values were considered statistically significant if $P<0.05$. The Tukey-Kramer or Steel-Dwass test after One-way ANOVA analysis was used to determine differences between groups.

\section{RESULTS}

Body and brain weights: No significant differences in BW or brain weight were found between the control and TCDDexposed groups (data not shown). 


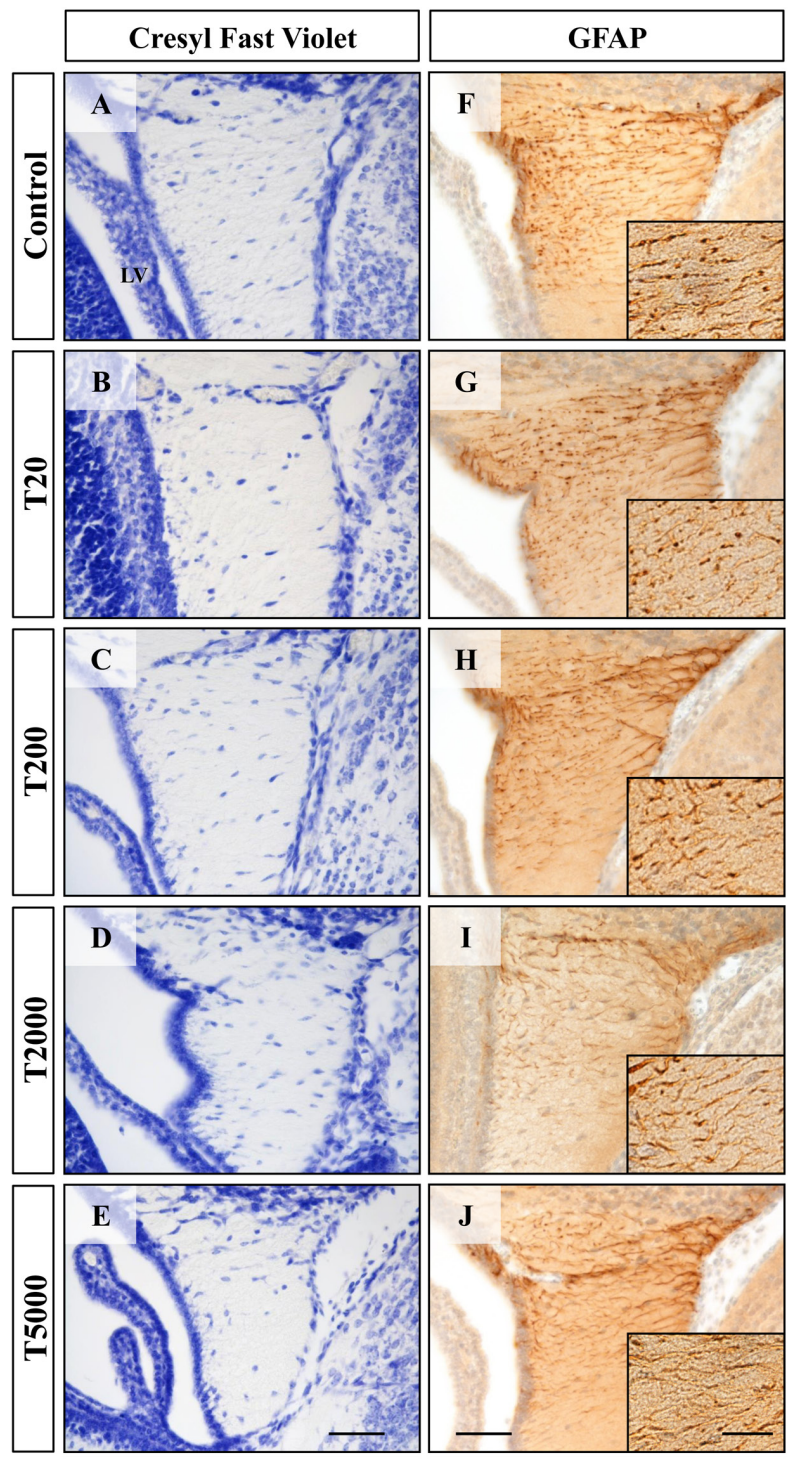

Fig. 2. Representative histology and immunohistochemistry in the hippocampal fimbria in the hippocampus at E18.5. (A-E) No notable differences were found between the control and TCDDexposed groups based on cresyl fast violet staining. (F-J) The fibrous and granular immunoreactivities of GFAP were observed, and the latter was reduced in the T5000 group (J). LV: lateral ventricle; Bar $=50 \mu \mathrm{m}$ (inset: $20 \mu \mathrm{m}$ ).

Histological findings: The DG at E18.5 was immature, and the granular cell layer could not be clearly distinguished from the molecular layer and polymorphic layer based on its morphology (Fig. 1A-1E). The cell density in the DG appeared to be decreased slightly in the T5000 group compared with the control group, whereas no obvious changes were observed in the shape or somatic size of cells. However, no notable differences in the hippocampal fimbria were found between the control and TCDD-exposed groups (Fig. 2A-2E).
A
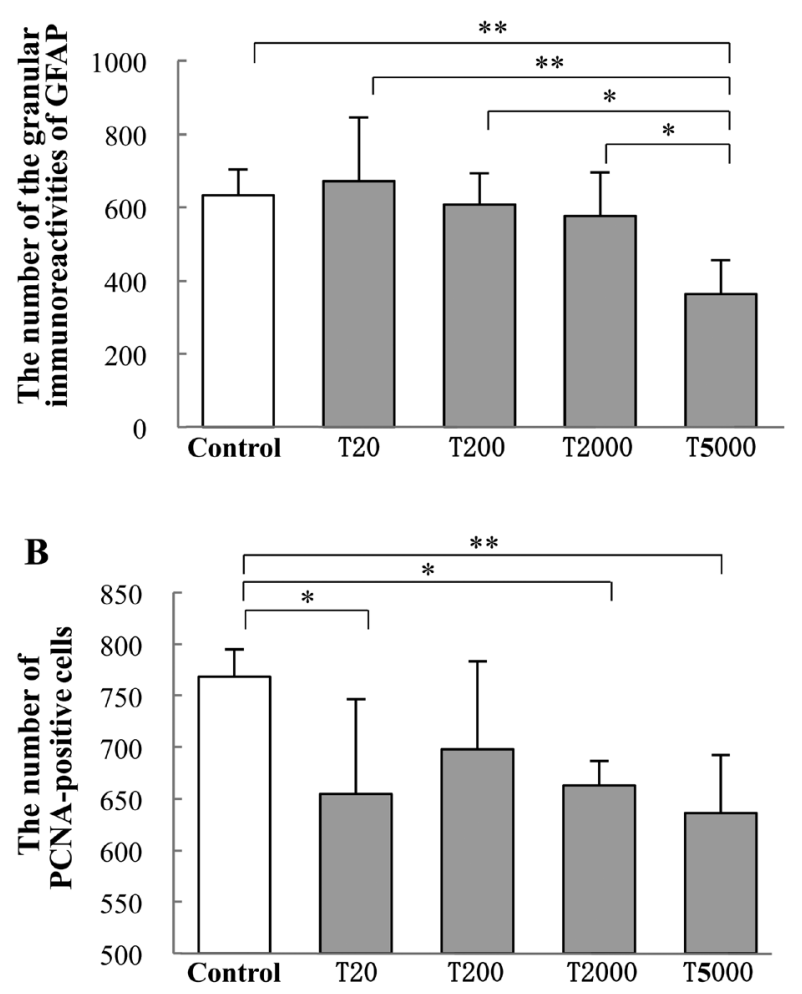

Fig. 3. The results of immunohistoplanimetry for the number of PCNA-positive cells in the DG (A) and the granular immunoreactivities of GFAP in the hippocampal fimbria (B). (A) The number of PCNA-positive cells was decreased in all TCDD-exposed groups and significantly reduced in the T20, T200 and T5000 groups. (B) The number of the granular immunoreactivities of GFAP was significantly decreased in the T5000 group. The values represent the mean \pm SD. $* P<0.05$, **P<0.01.

Immunohistological findings: The fibrous immunoreactivities of GFAP were detected in the cell body and process of neural stem cells (NSCs) and astrocytes in the DG. GFAP-immunoreactive NSCs and astrocytes were localized in the molecular layer, granular cell layer and next to the pia mater (Fig. 1F-1J). GFAP immunoreactivities in the DG were reduced in the T5000 group (Fig. 1J). In the hippocampal fimbria, the fibrous and granular GFAP immunoreactivities were observed in the cell body and process of NSCs and astrocytes (Fig. 2F-2J). The granular immunoreactivities of GFAP appeared to be reduced in the T5000 group, and in fact, the number of them was significantly decreased (Figs. 2J and 3A). The number of PCNA-positive cells was decreased in all TCDD-exposed groups and significantly reduced in the T20, T200 and T5000 groups (Figs. $1 \mathrm{~K}-1 \mathrm{O}$ and 3B). Doublecortin (DCX) immunoreactivity was detected in axons and dendrites of the immature neurons. The intensity of DCX staining did not differ between the control and TCDD-exposed groups (Fig. 1P-1T). 


\section{DISCUSSION}

This study demonstrated maternal TCDD exposure in $\mathrm{C} 57 \mathrm{BL} / 6 \mathrm{~N}$ mice disrupted the fetal hippocampal development at E18.5. To our knowledge, this is the first in vivo study reporting the effect of maternal exposure to TCDD on the DG and the hippocampal fimbria in fetal mice in which the decreases of the GFAP immunoreactivities and the number of PCNA positive cells in the DG, and the reduction of the number of granular GFAP immunoreactivities in the hippocampal fimbria were shown. These results suggest that the cumulative dioxins in fetus mediated via the placenta already affect the cells in the DG and the hippocampal fimbria in the fetal period and result in an adverse effect on the development of the hippocampus.

Neurons and glial cells in the DG derive from a pseudostratified neuroepithelium of ectodermal origin during early embryonic development. At around E9-10 in mice, cortical neurogenesis begins, and neuroepithelial cells begin to differentiate into radial glia (RG), which are NSCs and express GFAP [23]. The RG generates neurons directly or indirectly through neural precursor cells (NPCs). In the present study, the GFAP immunoreactivities were reduced in the DG of the T5000 group at E18.5, and the number of PCNA-positive cells was significantly reduced in the DG of the T20, T200 and T5000 groups at E18.5. Moreover, the cell density in the DG was decreased in the T5000 group compared with the control group. These results suggest that TCDD exposure impairs NSCs, NPCs or granular cells, resulting in a disruption of neuronal development in the fetal DG. We can suggest two possible explanations for these findings.

One possibility is that the proliferation of NSCs or NPCs was impaired. TCDD exposure is known to affect cell proliferation via the activation of Mitogen-activated Protein Kinases (MAPKs), such as ERK or JNK, and the induction of $\mathrm{p} 21^{\mathrm{Kip} 1}$ or $\mathrm{p} 27^{\mathrm{Waf} 1 / \mathrm{Cip} 1}$, which are involved in the cell cycle $[3,22,33,38]$. Moreover, TCDD also inhibits DNA synthesis in rat primary hepatocytes, and the proliferation of primary NPCs is arrested in the G1 phase of the cell cycle by TCDD exposure $[18,25]$. Considering that the AhR is present in proliferating NSCs and NPCs in vivo [2], TCDD exposure likely altered the proliferation of NSCs or NPCs in the present study, resulting in a reduction in the number of PCNA-positive cells.

Another possibility is that the number of cells in the hippocampus was reduced through the promotion of apoptosis. During the developmental period, a surplus of new neurons is produced, and the inappropriate neurons are excluded by apoptosis [7, 31]. As a result, the net number of neurons is properly retained. Therefore, apoptosis plays important roles in hippocampal formation in the developmental brain. It has been reported that AhR-mediated oxidative stress generated by the induction of cytochrome P450 enzymes may be an upstream event in the apoptosis cascade [29]. In addition, TCDD exposure has been shown to increase apoptosis of granule neuron precursor cells in the developing cerebellum [9]. In this study, it is possible that the mechanism for regulating the number of cells in the hippocampus was disrupted via TCDD-induced promotion of NSC, NPC or granular cell apoptosis.

In the hippocampus, astrocytes and NSCs express an astroglial intermediate filament, GFAP [4, 49]. Immunoreactivities of GFAP were observed fibrously and granularly in the hippocampal fimbria at E18.5. The former is considered as the cell processes of astrocytes and NSCs and the latter as the branching point of the cell process. The number of granular GFAP immunoreactivities was significantly decreased in the T5000 group, which may indicate the delay of astrogenesis. During embryonic development, RGs give rise to neurons first and glial cells later [42]. At the end of embryonic development, most NSCs begin to detach from the ventricular zone and convert into astrocytes [23]. So, it seemed that glial cell lines were more affected in E18.5. The basic helix-loop-helix genes Hes 1 and Hes 5 are known Notch signaling genes, and Hes 1 and Hes5 keep NSCs undifferentiated during early development and promote differentiation into glial cells [15]. In addition, it has been reported that the AhR regulates Hes1 [43]. These data suggest that the toxicity of TCDD mediated via the AhR disrupts the maintenance of NSCs at the point of their differentiation into astrocytes, resulting in the induction of developmental delay of astrogenesis in the hippocampal fimbria. The hippocampal fimbria is mainly composed of a band of efferent axons that forms part of the cerebral fornix. CA3 subcortical efferents in the hippocampal fimbria support the acquisition of contextual fear [17]. It is known that astrocytes surrounding the synapses participate in neurotransmission and that astrocytes are also an important component in glutamate uptake and metabolism [6]. Therefore, astrocytes are also considered to support neural activity in the hippocampal fimbria. These facts suggest that the developmental delay of astrocytes by TCDD exposure disrupts neuronal activity in the hippocampal fimbria.

In adult mice, new neurons are produced in the subgranular zone (SGZ) of the DG [8]. Unlike in fetal mice, radial astrocytes in the adult SGZ play a role as the primary precursors of new neurons in the adult hippocampus [36] and increased in SGZ differentiation into granular cells at 1-4 weeks [48]. Neurogenesis in the DG becomes persistent throughout postnatal life and is regulated by behavior and the environment [44]. The hippocampus is functionally engaged in learning and memory, and newborn cells are increased by hippocampal-dependent learning tasks [41, 47]. Therefore, it is suggested that neurogenesis exerts an influence on learning and memory. It has been reported that in utero and lactational exposure to dioxin deficit the fear memory of male offspring in adulthood, and latency in the active avoidance learning was longer in the TCDD exposed male offspring in the 41-44 postnatal day [13, 30]. Considering these reports, the effects of TCDD observed in the fetal period, such as the decrease in the numbers of GFAP- and PCNA-positive cells, may persist into adulthood, or neurogenesis in the DG may be negatively affected by TCDD exposure-mediated lactation.

Based on the present data, we conclude that maternal TCDD exposure has adverse impacts on NSCs, NPCs, 
granular cells or astrocytes in the DG or hippocampal fimbria, resulting in a disturbance of neuronal development in future generations of mice. It is possible that these effects remain until adulthood, and so, whether the influences of TCDD toxicity on the developing hippocampus persist and impair learning and memory in adulthood is needed to be examined as a further study.

ACKNOWLEDGMENT. This work was supported in part by a Grant-in-Aid for Scientific Research (no. 24590401) from the Ministry of Education, Culture, Sports, Science and Technology of Japan (to Hoshi N).

\section{REFERENCES}

1. Abbott, B. D. and Probst, M. R. 1995. Developmental expression of two members of a new class of transcription factors: II. Expression of aryl hydrocarbon receptor nuclear translocator in the C57BL/6N mouse embryo. Dev. Dyn. 204: 144-155. [Medline] [CrossRef]

2. Abbott, B. D., Birnbaum, L. S. and Perdew, G. H. 1995. Developmental expression of two members of a new class of transcription factors: I. Expression of aryl hydrocarbon receptor in the C57BL/6N mouse embryo. Dev. Dyn. 204: 133-143. [Medline] [CrossRef]

3. Barnes-Ellerbe, S., Knudsen, K. E. and Puga, A. 2004. 2,3,7,8-Tetrachlorodibenzo- $p$-dioxin blocks androgendependent cell proliferation of LNCaP cells through modulation of pRB phosphorylation. Mol. Pharmacol. 66: 502-511. [Medline] [CrossRef]

4. Benjelloun-Touimi, S., Jacque, C. M., Derer, P., De Vitry, F., Maunoury, R. and Dupouey, P. 1985. Evidence that mouse astrocytes may be derived from the radial glia. An immunohistochemical study of the cerebellum in the normal and reeler mouse. J. Neuroimmunol. 9: 87-97. [Medline] [CrossRef]

5. Bock, K. W. and Kohle, C. 2006. Ah receptor: dioxin-mediated toxic responses as hints to deregulated physiologic functions. Biochem. Pharmacol. 72: 393-404. [Medline] [CrossRef]

6. Chaboub, L. S. and Deneen, B. 2013. Astrocyte form and function in the developing central nervous system. Semin. Pediatr. Neurol. 20: 230-235. [Medline] [CrossRef]

7. Chan, W. Y., Lorke, D. E., Tiu, S. C. and Yew, D. T. 2002. Proliferation and apoptosis in the developing human neocortex. Anat. Rec. 267: 261-276. [Medline] [CrossRef]

8. Christie, B. R. and Cameron, H. A. 2006. Neurogenesis in the adult hippocampus. Hippocampus 16: 199-207. [Medline] [CrossRef]

9. Collins, L. L., Williamson, M. A., Thompson, B. D., Dever, D. P., Gasiewicz, T. A. and Opanashuk, L. A. 2008. 2,3,7,8-Tetracholorodibenzo- $p$-dioxin exposure disrupts granule neuron precursor maturation in the developing mouse cerebellum. Toxicol. Sci. 103: 125-136. [Medline] [CrossRef]

10. Endo, T., Kakeyama, M., Uemura, Y., Haijima, A., Okuno, H., Bito, H. and Tohyama, C. 2012. Executive function deficits and social-behavioral abnormality in mice exposed to a low dose of dioxin in utero and via lactation. PLOS ONE 7: e50741. [Medline] [CrossRef]

11. Gray, L. E., Ostby, J. S. and Kelce, W. R. 1997. A dose-response analysis of the reproductive effects of a single gestational dose of 2,3,7,8-tetrachlorodibenzo- $p$-dioxin in male Long Evans Hooded rat offspring. Toxicol. Appl. Pharmacol. 146: 11-20. [Medline] [CrossRef]
12. Gray, L. E., Wolf, C., Mann, P. and Ostby, J. S. 1997. In utero exposure to low doses of 2,3,7,8-tetrachlorodibenzo- $p$ dioxin alters reproductive development of female Long Evans hooded rat offspring. Toxicol. Appl. Pharmacol. 146: 237-244. [Medline] [CrossRef]

13. Haijima, A., Endo, T., Zhang, Y., Miyazaki, W., Kakeyama, M. and Tohyama, C. 2010. In utero and lactational exposure to low doses of chlorinated and brominated dioxins induces deficits in the fear memory of male mice. Neurotoxicology 31: 385-390. [Medline] [CrossRef]

14. Hirako, M., Aoki, M., Kimura, K., Hanafusa, Y., Ishizaki, H. and Kariya, Y. 2005. Comparison of the concentrations of polychlorinated dibenzo- $p$-dioxins, dibenzofurans, and dioxinlike polychlorinated biphenyls in maternal and fetal blood, amniotic and allantoic fluids in cattle. Reprod. Toxicol. 20: 247-254. [Medline] [CrossRef]

15. Hojo, M., Ohtsuka, T., Hashimoto, N., Gradwohl, G., Guillemot, F. and Kageyama, R. 2000. Glial cell fate specification modulated by the bHLH gene Hes5 in mouse retina. Development 127 : 2515-2522. [Medline]

16. Hoshi, N., Hirano, T., Omotehara, T., Tokumoto, J., Umemura, Y., Mantani, Y., Tanida, T., Warita, K., Tabuchi, Y., Yokoyama, T. and Kitagawa, H. 2014. Insight into the mechanism of reproductive dysfunction caused by neonicotinoid pesticides. Biol. Pharm. Bull. 37: 1439-1443. [Medline] [CrossRef]

17. Hunsaker, M. R., Tran, G. T. and Kesner, R. P. 2009. A behavioural analysis of the role of CA3 and CA1 subcortical efferents during classical fear conditioning. Behav. Neurosci. 123: 624-630. [Medline] [CrossRef]

18. Hushka, D. R. and Greenlee, W. F. 1995. 2,3,7,8-Tetrachlorodibenzo-p-dioxin inhibits DNA synthesis in rat primary hepatocytes. Mutat. Res. 333: 89-99. [Medline] [CrossRef]

19. Ishihara, K., Ohsako, S., Tasaka, K., Harayama, H., Miyake, M., Warita, K., Tanida, T., Mitsuhashi, T., Nanmori, T., Tabuchi, Y., Yokoyama, T., Kitagawa, H. and Hoshi, N. 2010. When does the sex ratio of offspring of the paternal 2,3,7,8-tetrachlorodibenzo$p$-dioxin (TCDD) exposure decrease: in the spermatozoa stage or at fertilization? Reprod. Toxicol. 29: 68-73. [Medline] [CrossRef]

20. Ishihara, K., Warita, K., Tanida, T., Sugawara, T., Kitagawa, H. and Hoshi, N. 2007. Does paternal exposure to 2,3,7,8-tetrachlorodibenzo- $p$-dioxin (TCDD) affect the sex ratio of offspring? J. Vet. Med. Sci. 69: 347-352. [Medline] [CrossRef]

21. Kim, M. E., Park, H. R., Gong, E. J., Choi, S. Y., Kim, H. S. and Lee, J. 2011. Exposure to bisphenol A appears to impair hippocampal neurogenesis and spatial learning and memory. Food Chem. Toxicol. 49: 3383-3389. [Medline] [CrossRef]

22. Kolluri, S. K., Weiss, C., Koff, A. and Göttlicher, M. 1999. p27 $7^{\text {kip } 1}$ induction and inhibition of proliferation by the intracellular $\mathrm{Ah}$ receptor in developing thymus and hepatoma cells. Genes Dev. 13: 1742-1753. [Medline] [CrossRef]

23. Kriegstein, A. and Alvarez-Buylla, A. 2009. The glial nature of embryonic and adult neural stem cells. Annu. Rev. Neurosci. 32: 149-184. [Medline] [CrossRef]

24. Latchney, S. E., Hein, A. M., O’Banion, M. K., DiCicco-Bloom, E. and Opanashuk, L. A. 2013. Deletion or activation of the aryl hydrocarbon receptor alters adult hippocampal neurogenesis and contextual fear memory. J. Neurochem. 125: 430-445. [Medline] [CrossRef]

25. Latchney, S. E., Lioy, D. T., Henry, E. C., Gasiewicz, T. A., Strathmann, F. G., Mayer-Proschel, M. and Opanashuk, 
L. A. 2011. Neural precursor cell proliferation is disrupted through activation of the aryl hydrocarbon receptor by 2,3,7,8-tetrachlorodibenzo- $p$-dioxin. Stem Cells Dev. 20: 313326. [Medline] [CrossRef]

26. Matikainen, T. M., Moriyama, T., Morita, Y., Perez, G. I., Korsmeyer, S. J., Sherr, D. H. and Tilly, J. L. 2002. Ligand activation of the aromatic hydrocarbon receptor transcription factor drives Bax-dependent apoptosis in developing fetal ovarian germ cells. Endocrinology 143: 615-620. [Medline] [CrossRef]

27. Matikainen, T., Perez, G. I., Jurisicova, A., Schlezinger, J. J., Ryu, H.Y., Pru, J. K., Sakai, T., Korsmeyer, S. J., Casper, R. F., Sherr, D. H. and Tilly, J. L. 2001. Aromatic hydrocarbon receptordriven Bax gene expression is required for premature ovarian failure caused by biohazardous environmental chemicals. Nat. Genet. 28: 355-360. [Medline] [CrossRef]

28. Mimura, J. and Fujii-Kuriyama, Y. 2003. Functional role of AhR in the expression of toxic effects by TCDD. Biochim. Biophys. Acta 1619: 263-268. [Medline] [CrossRef]

29. Nebert, D. W., Roe, A. L., Dieter, M. Z., Solis, W. A., Yang, Y. and Dalton, T. P. 2000. Role of the aromatic hydrocarbon receptor and $[\mathrm{Ah}]$ gene battery in the oxidative stress response, cell cycle control, and apoptosis. Biochem. Pharmacol. 59: 65-85. [Medline] [CrossRef]

30. Nishijo, M., Kuriwaki, J., Hori, E., Tawara, K., Nakagawa, H. and Nishijo, H. 2007. Effects of maternal exposure to 2,3,7,8-tetrachlorodibenzo- $p$-dioxin on fetal brain growth and motor and behavioral development in offspring rats. Toxicol. Lett. 173: 41-47. [Medline] [CrossRef]

31. Oppenheim, R. W. 1991. Cell death during development of the nervous system. Annu. Rev. Neurosci. 14: 453-501. [Medline] [CrossRef]

32. Petersen, S. L., Curran, M. A., Marconi, S. A., Carpenter, C. D., Lubbers, L. S. and McAbee, M. D. 2000. Distribution of mRNAs encoding the arylhydrocarbon receptor, arylhydrocarbon receptor nuclear translocator, and arylhydrocarbon receptor nuclear translocator-2 in the rat brain and brainstem. J. Comp. Neurol. 427: 428-439. [Medline] [CrossRef]

33. Puga, A., Nebert, D. W. and Carrier, F. 1992. Dioxin induces expression of c-fos and c-jun proto-oncogenes and a large increase in transcription factor AP-1. DNA Cell Biol. 11: 269281. [Medline] [CrossRef]

34. Rolls, E. T. 2000. Memory systems in the brain. Annu. Rev. Psychol. 51: 599-630. [Medline] [CrossRef]

35. Schantz, S. L. and Bowman, R. E. 1989. Learning in monkeys exposed perinatally to 2,3,7,8-tetrachlorodibenzo- $p$-dioxin (TCDD). Neurotoxicol. Teratol. 11: 13-19. [Medline] [CrossRef]

36. Steiner, B., Kronenberg, G., Jessberger, S., Brandt, M. D., Reuter, K. and Kempermann, G. 2004. Differential regulation of gliogenesis in the context of adult hippocampal neurogenesis in mice. Glia 46: 41-52. [Medline] [CrossRef]

37. Suzuki, G., Nakano, M. and Nakano, S. 2005. Distribution of PCDDs/PCDFs and Co-PCBs in human maternal blood, cord blood, placenta, milk, and adipose tissue: dioxins showing high toxic equivalency factor accumulate in the placenta. Biosci. Biotechnol. Biochem. 69: 1836-1847. [Medline] [CrossRef]

38. Tan, Z., Chang, X., Puga, A. and Xia, Y. 2002. Activation of mitogen-activated protein kinases (MAPKs) by aromatic hydrocarbons: role in the regulation of aryl hydrocarbon receptor
(AHR) function. Biochem. Pharmacol. 64: 771-780. [Medline] [CrossRef]

39. Tanida, T., Tasaka, K., Akahoshi, E., Ishihara-Sugano, M., Saito, M., Kawata, S., Danjo, M., Tokumoto, J., Mantani, Y., Nagahara, D., Tabuchi, Y., Yokoyama, T., Kitagawa, H., Kawata, M. and Hoshi, N. 2014. Fetal exposure to 2,3,7,8-tetrachlorodibenzo$p$-dioxin transactivates aryl hydrocarbon receptor-responsive element III in the tyrosine hydroxylase immunoreactive neurons of the mouse midbrain. J. Appl. Toxicol. 34: 117-126. [Medline] [CrossRef]

40. Tanida, T., Warita, K., Ishihara, K., Fukui, S., Mitsuhashi, T., Sugawara, T., Tabuchi, Y., Nanmori, T., Qi, W. M., Inamoto, T., Yokoyama, T., Kitagawa, H. and Hoshi, N. 2009. Fetal and neonatal exposure to three typical environmental chemicals with different mechanisms of action: mixed exposure to phenol, phthalate, and dioxin cancels the effects of sole exposure on mouse midbrain dopaminergic nuclei. Toxicol. Lett. 189: 40-47. [Medline] [CrossRef]

41. Taupin, P. 2007. BrdU immunohistochemistry for studying adult neurogenesis: paradigms, pitfalls, limitations, and validation. Brain Res. Rev. 53: 198-214. [Medline] [CrossRef]

42. Temple, S. 2001. The development of neural stem cells. Nature 414: 112-117. [Medline] [CrossRef]

43. Thomsen, J. S., Kietz, S., Ström, A. and Gustafsson, J. A. 2004. HES-1, a novel target gene for the aryl hydrocarbon receptor. Mol. Pharmacol. 65: 165-171. [Medline] [CrossRef]

44. Uda, M., Ishido, M., Kami, K. and Masuhara, M. 2006. Effects of chronic treadmill running on neurogenesis in the dentate gyrus of the hippocampus of adult rat. Brain Res. 1104: 64-72. [Medline] [CrossRef]

45. Ulaszewska, M. M., Zuccato, E., Capri, E., Iovine, R., Colombo, A., Rotella, G., Generoso, C., Grassi, P., Melis, M. and Fanelli, R. 2011. The effect of waste combustion on the occurrence of polychlorinated dibenzo- $p$-dioxins (PCDDs), polychlorinated dibenzofurans (PCDFs) and polychlorinated biphenyls (PCBs) in breast milk in Italy. Chemosphere 82: 1-8. [Medline] [CrossRef]

46. Van den Berg, M., Birnbaum, L. S., Denison, M., De Vito, M., Farland, W., Feeley, M., Fiedler, H., Hakansson, H., Hanberg, A., Haws, L., Rose, M., Safe, S., Schrenk, D., Tohyama, C., Tritscher, A., Tuomisto, J., Tysklind, M., Walker, N. and Peterson, R. E. 2006. The 2005 World Health Organization reevaluation of human and Mammalian toxic equivalency factors for dioxins and dioxin-like compounds. Toxicol. Sci. 93: 223-241. [Medline] [CrossRef]

47. van Praag, H., Christie, B. R., Sejnowski, T. J. and Gage, F. H. 1999. Running enhances neurogenesis, learning, and long-term potentiation in mice. Proc. Natl. Acad. Sci. U.S.A. 96: 1342713431. [Medline] [CrossRef]

48. van Praag, H., Schinder, A. F., Christie, B. R., Toni, N., Palmer, T. D. and Gage, F. H. 2002. Functional neurogenesis in the adult hippocampus. Nature 415: 1030-1034. [Medline] [CrossRef]

49. von Bohlen und Halbach, O. 2011. Immunohistological markers for proliferative events, gliogenesis, and neurogenesis within the adult hippocampus. Cell Tissue Res. 345: 1-19. [Medline] [CrossRef]

50. Watanabe, S., Kitamura, K. and Nagahashi, M. 1999. Effects of dioxins on human health: a review. J. Epidemiol. 9: 1-13. [Medline] [CrossRef] 